\title{
Advantages of using CLIL methodology in the process of future English language teachers' study in contemporary higher educational establishments of Ukraine
}

\author{
I. V. Shevchenko, O. M. Kordyuk \\ V.O. Suhkomlynsky National University of Mykolaiv, Mykolaiv, Ukraine \\ Corresponding author. E-mail: shevchenko2011@gmail.com \\ Paper received 01.06.18; Accepted for publication 09.06.18.
}

\section{https://doi.org/10.31174/SEND-PP2018-170VI70-12}

\begin{abstract}
The article is dedicated to the issues of using CLIL methodology in the process of future English language teachers' study in contemporary higher educational establishments of Ukraine. The general principles of the methodology, its advantages and disadvantages are explained. The peculiarities of planning and carrying out classes after CLIL methodology, selection of tasks and their types are pointed out.
\end{abstract}

Keywords: CLIL methodology, future English language teachers, motivation, the content of study.

Problem statement. Involving Ukrainian higher education system to the Bologna process was the beginning of its reformation and Ukrainian higher educational establishments are undergoing the complicated process of agreement of their language programs with contemporary conditions of possessing language competences. The primary purpose of both Bachelors and Masters programs is in creating professional communicative competences of students-philologists, i.e. the ability to solve communicative tasks in the frames of their professional activity. Many graduates aspire to work not only as teachers of secondary educational establishments, but also in big transnational companies, where the office language is English. Therefore, the increasing pressure of globalization changes our images of education, and good knowledge continues to provide the employment of future graduates. In this context of learning the English language with the purpose of further development of their own career is becoming extremely relevant. And the accent of learning the language is being replaced to immediacy and clearness of communication.

Decreasing class hours and giving a great amount of hours to individual study requires from teachers to reconsider the traditional methodology of learning the English language and turn to contemporary world experience.

CLIL methodology of studying foreign languages is becoming more and more widespread in the world practice.

Analysis of contemporary researches and publications. Such scholars as S.Bobil, Y. Roudnik, and others focused their attention on the problem of content and language integrated learning.

Among foreign researchers of the problem of content and language integrated learning we could point out $\mathrm{M}$. Allen, A. Bonne, D. Greddol, M.Hajer, L. Collins, D. Marsh, I. Ting and many others.

Purpose of the article. To analyze the main advantages and disadvantages of CLIL methodology in the process of future English language teachers' study in contemporary higher educational establishments of Ukraine.

Presentation of the principal material. The term CLIL was developed in 1994 by David Marsh, who was the first to describe the methodological approach according to which a foreign language is learnt in integrated way. "CLIL corresponds to situations when subjects or their parts are studied in a foreign language with a double purpose, in particular studying the content with simultaneous learning the foreign language" [7].

The purpose of "double focus" presupposes that CLIL works in two ways. Based on integrated interdisciplinary approach CLIL differs from all other approaches to language learning and studying. Many researches emphasize that CLIL methodology contributes not only to improving learners' knowledge, but also to acquiring intercultural knowledge. Contributing to the development of various teaching strategies and involving innovative methods of learning, textbooks encourage cognitive development and study in general. Besides, CLIL gives another advantage to an educational establishment, namely - a better time control [7].

In his book "Framework for Task-Based Learning" J. Willis defines tasks as an activity when a language is used by learners with communicative purpose. The result of assessment depends primarily on the result of the task, but not on the language accuracy. This makes CLIL particularly important for a learner's general development, thus breaking psychological barriers and doing away with the fear of making an error. CLIL has a worldwide support in the educational society, because it gives a great flexibility, a wide range of stimulating open tasks (thematic researches, tasks aimed at a problem solution, role-plays, exercise for listening and reading, for further discussing, presentations, negotiations, etc [10].

One of the most outstanding scholars Jon Larsson considers as one of the main advantages of CLIL reproduction of an essential improvement in learners' communicative skills and general abilities of social interrelation, that are the most important factors for a language learning [5].

Scholar Fernandes states that CLIL is a flexible method which helps to learn a foreign language. Comparing with other methods of learning, CLIL is effective, because knowledge of a particular subject provides learners with motivation for studying a foreign language.

According to CLIL methodology a foreign language is the language of instruction in educational content, that makes a language a means of learning the subject content, whereas the content makes it possible to learn a foreign language with the help of authentic communicative contexts [9]. 
According to Coyle the content of learning a foreign language concerns the knowledge of particular subject researches, such as science and arts. In CLIL context the choice of content changes in regard of a definite purpose. It is necessary to take into consideration the availability of qualified teachers, the level of those who study, their language competence and learning background. The content in learning-methodological background by CLIL method can be chosen from a traditional school curriculum, for instance physics, chemistry, mathematics, geography or even music; this can be a national curriculum or project, such as ecosystem, summit of APEC general secretary, global warming; it must also be intersectional or interdisciplinary. Thus, CLIL gives the opportunities both in frames of an ordinary curriculum and out of these frames to enrich knowledge and skills, and learners' cognitive involvement also requires being taken into account [2].

A great importance is being acquired by the activity of a teacher in defining CLIL content, as he holds the balance between learners' cognitive demand, their growth and general progress in study. Defining the content is the process of cognitive interaction, problems solution and development of creative thinking. To support effective learning using CLIL methodology learners' cognitive activity should be taken into account. Learners must be able to think individually, set new creative tasks, be interested, capable of taking the responsibility for their own construction of knowledge and management of study.

It is important to pay attention to four factors of CLIL methodology that have some similarity with other previous approaches to language learning.

The first peculiarity is naturalistic and implicit style of CLIL methodology. According to scholar Jarvinen, naturalistic and implicit style of CLIL learning should be understood as increasing possibilities for communication owing to greater focus on incoming data that a learner gets from outer environment. A great deal of information provides better results of study.

The second peculiarity of CLIL is the style of cooperative learning. While cooperative learning learners, as a rule, are divided into small groups to fulfill tasks through team work. Cooperative style of learning is effective as it gives the possibility to do away with the fear in the process of study, to stimulate learners' motivation and encourage their interaction. Autonomy of learners, created in the frames of cooperative approach to and interaction with a team member contributes to improving their communicability while learning the language.

The third peculiarity of CLIL is authenticity which allows learners to develop the capability to solve communicative problems in real life. In the course of authentic oriented learning materials are selected taking into account real language surrounding.

The fourth peculiarity of CLIL is flexibility. CLIL methodology can be used for being implemented into different curricula with different content of subject researches [4].

Despite of the fact that the notion has appeared relatively recently, the roots of integrated learning date back to distant times, beginning with early Babylonians up to the beginning of 60 s of this century, when bilingual learning acquired great popularity all over the world.
The use of a foreign language in CLIL education depends on set educational tasks and goals. CLIL combines a number of theories and approaches which are used un different educational contexts. There are several terms that describe different methods of CLIL implementation, for example full language exposure, "language flood", etc.

In defining main principles of CLIL methodological approach in different European countries they define four basic aspects which embrace cultural and language surrounding and are aimed at solving subject and educational tasks. Each of the four aspects is realized in different ways depending on the age of learners, social-linguistic background and the level of being exposed in CLIL.

The idea of using the principle of content and language integrated learning appeared as a result of growing requirements to the level of a foreign language possession in the conditions of limited hours given to its learning. Teachers almost in all countries of the world face this problem $[3,6,8]$.

This approach allows to carry out teaching in two subjects simultaneously, though a special attention can be given to language and non-language subjects.

Language learning becomes more goal-seeking as the language is used for solving definite communicative tasks. Besides, learners have the chance to become better acquainted and understand the culture of the language under study which leads to formation of learners' socialcultural competence.

A learner transmits quite a great volume of language material which is a full-scale exposure into natural language background. It is also necessary to point out the fact that the work with different topics lets study specific terms, certain language constructions, which contributes to enriching a leaner's vocabulary with content terminology and prepares him for further study and implementation of acquired knowledge and skills. Learning a foreign language and a non-language subject simultaneously is an additional means of achieving educational goals and has positive sides both for learning the foreign language and the non-language subject [4].

In our work we will consider the definition of CLIL suggested by Kochenkova O.M. In her opinion, this is a didactic methodology that allows to form in learners linguistic and communicative competences in a foreign language in the same educational context in which they undergo the formation of general knowledge and skills. [1]. Notwithstanding the advantage of the suggested methodology, its relevance and importance, the scholars point to the lack of learning materials as well as the absence of the programs of teachers' training.

A lesson that is carried out according to the methodology of content and language integrated learning must combine the following aspects:

- Taking into account a learner's knowledge and skills connected with definite elements of his professional studies.

- Using the language as a source of acquired and improved professional knowledge.

- Development of the language culture. Researches of the culture of the language under study, encouraging socialization in multicultural surrounding.

- Realizing intercultural links. 
The use of CLIL methodology in classes presupposes the involvement of four types of language activity:

- Listening comprehension which allows to speak a foreign language in professional context.

- Reading, which is the primary source of introduction new lexical units due to the use of authentic professional material.

- Writing, which improves assimilation of new material, enriches vocabulary and is the basis for development and establishment intercultural professional ties.

A teacher who plans his educational activity ought to:

- take into consideration teaching a language and developing learners' skills, avoid overloading and redundancy of terms;

- not to use excessively reading or listening to texts or extracts;

- use different tasks and exercises [1].

Goal, content, structure, purposefulness, methods and means of work according to the methodology of content and language integrated learning must reflect communicative focus of every separate lesson and the system of lessons in general. To achieve the above mentioned tasks one must follow such principles as:

1. While preparing for a lesson one should realize that this is the element of the system, consecutive step to achieving the main goal. Complex approach to planning takes into account the structure of the topic under study, unit, etc.

2. The goal of the lesson is the opening phase of projecting studies which required the achievement of diagnostic and operative tasks. It should not be too broad, one ought to take into consideration the fact that to achieve it certain time is given.

3. A learner's activity must be fruitful. New material demands involving into the learner's language practice solving different tasks, establishing links between new and already known language phenomena. Any type of the learner's activity must have personal content of fulfillment.

4. A lesson of foreign language must be built on solution of real, not imaginary tasks and problems.

5. Communicative focus of learning must be reflected in variety of organizational forms of the process of study. They help a teacher to create such situations of communication which are maximum close to real life.

6. A teacher is am equal participant of the dialogue with a leaner. The task of the teacher is not to be an outside observer, but to actually take part in the process of communication, to maximum precisely represent the real situation.

A lesson that is carried out using CLIL methodology presupposes work with text material. It is considered sensible to support texts with illustrations so that learners could visualize what they are reading. While working with authentic material learners must mark off structure markers in texts. These markers can be linguistic (headline, subtitle) and schemes, diagrams, etc. After the "basic markers" have been defined, the text structure and content can be analyzed [1].

To organize lexical material it is important to use schemes to help learners to classify ideas and the information in the text. Types of diagrams can vary for classification of groups, hierarchy, as instructions and additional information, tables that describe people and places, as well as their combinations. Structuring texts is used to make the process of learning easier and create methods aimed at developing language skills.

Learners must be able to recreate the content of the material they read in their own words. A teacher must pay attention to whether learners use the comparison of lexical units, antithesis, description, discourse markers, academic and professional vocabulary.

There is no great difference in tasks on lessons when CLIL methodology is used and ordinary lessons. There should be offered different types of exercises, taking into consideration educational goals. Such list of tasks can be offered:

- Listen to the text and make a diagram/representation/map/

graph.

- Listen to the text and fill in the table.

- Listen to the text and note certain information (dates, figures, etc)

- Listen to the text and make up a plan for it, annotation, etc.

- Listen to the text and define the stages of the process/instructions/sequence of actions.

- Listen to the text and fill in the blanks in it.

According to the CLIL methodology learners acquire knowledge of a subject from the curriculum together with simultaneous learning and using a foreign language. CLIL methodology has an advantage in solving the problem of "overloaded curriculum" as it allows to combine one or several aspects of the curriculum and increases the amount of hours for learning the language.

However, there are important factors which must be taken into account before implementing CLIL programs. They are as follows:

- available qualified teaching staff;

- the necessity of cooperation of different subject teachers;

- provision of learners with key terms and concepts in a foreign language;

- the possibility of changing schedules required for CLIL program realization (it includes time of planning academic programs).

Conclusions and proposals. So, in contemporary conditions of changing class hours for the English language learning and the necessity of training high level professional specialists for using CLIL methodology is becoming especially important. CLIL methodology that is based on integrated interdisciplinary approach contributes to acquiring intercultural knowledge, developing learners; creative thinking, forming both professional and general language competences. 


\section{REFERENCES}

1. Kochenkova O.M. Possibilities of professional training of teaching foreign languages by means of using the elements of CLIL methodology (integration of teaching a foreign language and other academic subjects)

[Electronic resource]. - Access mode: http://kochenkova.ru/publ/vozmozhnosti_profilizacii_prepoda vanija_inost

rannykh_jazykov_s_pomoshhju_primenenija_ehlementov_meto diki_clil_i ntegrirovanie_prepodavanija_inostrann/1-1-0-1

2. Coyle, D., Hood, P., \& Marsh, D. (2010). CLIL: content and language integrated learning / Coyle, D., Hood, P., \& Marsh, D. - Cambridge, UK: Cambridge University Press.European Network on Education. (2007). Key data on higher education in Europe (p. 20-60). Luxembourg, LU: Office for Official Publications of the European Communities.

3. Hajer M. Creating a language-promoting classroom: contentarea teacher sat work. In Hall, Joan Kelly and Lorrie Stoops Verplaetse (eds.) /M. Hajer, L.Maaike. - Second and foreign language learning through classroom interaction. Mahwah N.J. and London: Lawrence Erlbaum Associates. - 2000. pp. 265-285.

4. Jarvinen, H. Acquisition of English in content and language integrated learning at elementary level in the Finnish comprehensive school / H. Jarvinen. - Turku: University of Turku. -1999.

5. Larsson, Jon. Problem-Based Learning: A possible Approach to Language Education? / Jon Larsson. Polonia Institute, Jagiellonian University, 2001. - Retrieved 27 January 2013.
6. Lorenzo W. E.. Immersioneducation a l'americaine: Adescriptive study of USimmersion programs / W. E.Lorenzo, Gladstein L.A. Foreign Language Annals, 17(1) - 1984. - p.p. 3542.

7. Marsh D. Content and Language Integrated Learning: The European Dimension - Actions, Trends and Foresight Potential / D. Marsh // Retrieved December 18, 2016, [Електронний pecypc]. - Режим доступу: fromhttp://europa.eu.int/comm/education/languages/index/ht ml. - Назва з екрану.

8. Vollmer G. Helmut Johannes, Lena Heine, Randi Troschke, Debbie Coetzee, Verena Kuttel. 2006. Subject-specific competence and language use of CLIL learners: The case of geography in grade 10 of secondary schools in Germany / G. Vollmer, Helmut Johannes, Lena Heine, Randi Troschke, Debbie Coetzee, Verena Kuttel // Paper presented at the ESSE8 Conference in London, 29 August 2006. - pp.22-25

9. Wang X. "Investigating students' listening and speaking communication and perceptions through the implementation of Chinese culture content-based course." / Wang, Xingchun. - Language In India, June 2016, p. 217+. Academic OneFile, http://link.galegroup.com/apps/doc/A459894914/AONE ?u=wash89460\&sid=AONE. Accessed 30 Jan. 2018.

10. Willis, J. A. Framework for Task-Based Learning/, J. A. Willis. - Harlow. England: Pearson Longman, 1996. VanPatten, Bill; Benati, Alessandro G. Key Terms in Second Language Acquisition. London: Continuum, 2010.

Преимущества использования методики CLIL в процессе подготовки будущих учителей английского языка в высших учебных заведениях Украины

\section{И. В. Шевченко, Е. Н. Кордюк}

Аннотация. Статья посвящена проблеме использования методики CLIL в процессе подготовки будущих учителей английского языка в высших учебных заведениях Украины. Общие принцыпы методики, основные ее преимущества и недостатки объяснены. Внимание уделяется особенностям планирования и проведения уроков, используя методику CLIL, предложены здания и их виды.

Ключевые слова: методика CLIL, будущие учителя английского языка, мотивачия, содержание обучения. 